\title{
sciendo
}

CIVIL AND ENVIRONMENTAL ENGINEERING REPORTS

E-ISSN 2450-8594

CEER 2021; 31 (2): 0163-0177

DOI: 10.2478/ceer-2021-0025

Original Research Article

\section{EXPERIMENTAL INVESTIGATION OF SELF- COMPACTING CONCRETE CONTAINING COIR FIBRES}

\author{
Muhammad Tarique LAKHIAR ${ }^{1 *}$, Muhammad Tahir LAKHIAR ${ }^{2}$, \\ Abd Halid ABDULLAH ${ }^{1}$, Noridah MOHAMAD ${ }^{1}$ \\ ${ }^{1}$ Faculty of Civil Engineering and Built Environment, UTHM, Johar, Malaysia \\ ${ }^{2}$ Faculty of Engineering, Monash University, Selangor Malaysia
}

\begin{abstract}
Many researchers have investigated alternative sources to overcome the problem of conventional building material polluting the environment by the development of green self-compacting concrete in the construction industry. The best alternative solution is to utilise non-conventional construction materials like agricultural wastes. Meanwhile, selfcompacting concrete (SCC) is considered as high strength as well as high-performance concrete. The demerits, which include tensile and flexural strength, can be improved by incorporating coir fibres. The utilisation of coir fibres also modifies self-compacting concrete performance after cracking and improves the toughness. This study defines an experimental investigation of the mechanical properties of self-compacting concrete containing coir fibres (CF) with different percentages being $0 \%, 0.2 \%, 0.5 \%, 1 \%$, and $1.5 \%$ at 7 - and 28 -days water curing. The mechanical properties include the slump flow and compressive and tensile strength were examined. The outcomes demonstrated that a required slump flow for self-compacting concrete was achieved using coir fibres up to $1 \%$, beyond which it reduced the slump significantly. The length of fibre and proportion of fibres directly affected the workability. The compressive strength was $10 \%$ to $15 \%$ enhanced with the incorporation of coir fibres up to $0.5 \%$; after that, the strength was slightly reduced, and tensile strength was $30 \%$ to $50 \%$ improved compared to conventional
\end{abstract}

\footnotetext{
$1 *$ Corresponding author: Faculty of Civil Engineering and Built Environment, UTHM, Johar, Malaysia, e-mail: mtarique181@gmail.com
} 
self-compacting concrete up to $1 \%$ of coir fibres incorporation in the SCC mix, after which it rapidly reduced.

Keywords: self-compacting concrete, coir fibre, slump flow, compressive strength, split tensile strength

\section{INTRODUCTION}

Many scholars wish to introduce new and innovative systems that will fulfil future demands for construction. The conventional systems adopted in the construction industry, including reinforced concrete, load-bearing structures, brickwork, timber work, and many others, do not satisfy the current demand. This moves development towards new innovative construction system, including IBS, which includes various methods and benefits that will be highly preferable in the future [1-4]. SCC tends to flow under its own weight, even in dense reinforcement or irregular shapes; SCC possesses both high strength and high performance [5], and is, therefore, one of the most beneficial products in the construction industry. At present, it is widely utilised. SCC has greater compressive strength than flexural and tensile strength because it is brittle [6] so, in order too enhance the tensile and flexural strength of SCC, reinforcement is required. Steel fibres are most commonly used in concrete. The manufacturing process of steel emits $7 \%$ of the total carbon dioxide $\left(\mathrm{CO}_{2}\right)$ in the atmosphere [9] and the use of steel fibres contributes to increasing project costs and decreasing concrete durability when exposed to an aggressive environment [10]. Simultaneously, the generation of agricultural waste also increases with respect to time, creating environmental and disposal problems [11-12]. To overcome these issues, agricultural waste such as coir fibre can be utilised in SCC to enhance its tensile and flexural strength. Furthermore, this has the potential to decrease the emission of $\mathrm{CO}$, environmental pollution, disposal of waste, and increase resistance to stresses at a high level, making the concrete more ductile. In this study, the compressive and the tensile strength as well as the slump flow were investigated to analyse the behaviour of SCC when coir fibres are introduced.

\section{LITERATURE REVIEW}

In Malaysia, approximately 150,000 hectares of agricultural land are used for coconut plantations [13]. Coir fibre and shell are the by-products of the manufacture of coconut oil. Coir fibre is utilised as a reinforcement material in concrete to reduce environmental pollution and make the manufacture of concrete more economical [14]. Many researchers have conducted experimental work on coir fibre used as a reinforcement material in concrete. Jhatial [16] analysed the fresh and hardened properties of steel fibre concrete. The steel fibre was added in 
different proportions; $1 \%, 2 \%, 3 \%, 4 \%$, and $5 \%$. The results demonstrated that the steel fibres in concrete decreased its workability. Simultaneously, the compressive and flexural strength were increased up to $3 \%$ and $5 \%$, respectively, at the $3 \%$ optimum addition of steel fibre. Athiyamaan \& Ganesh [17] also analysed the flexural performance of SCC by utilising steel fibre as a filler.

In contrast, fly ash and nano-silica were partially replaced with cement. Hence, Fly ash $(30 \%)$ and micro silica fume $(10 \%)$ are mineral admixtures replaced with cement. The results demonstrated that an SCC beam's flexural performance was enhanced up to $63 \%$ in terms of ultimate load. Ghorbani [18] examined the impact of magnetised water on the mechanical characteristics of SCC by adding steel fibres in different proportions being $0 \%, 0.35 \%, 1 \%$, and $1.65 \%$. The results showed that the new state properties of SCC decrease as the amount of steel fibre increases in the concrete.

In contrast, strength properties show that SCC mixtures are relatively improved by magnetising the mixing water. Yan [15] investigated the mechanical properties of concrete by utilising various percentages such as $0.5 \%, 1.0 \%, 1.5 \%, 2.0 \%$, and $2.5 \%$ of basalt, polypropylene, and glass fibre. The results show that the basalt, polypropylene, and glass fibre significantly affect the modulus of elasticity and compressive and flexural strength; as the content of fibre increases in the concrete mix, the modulus of elasticity and compressive and flexural strength also increases. Tahir [19] examined the material, mechanical, and structural properties of SCC reinforced with $0.5 \%$ and $1 \%$ coir fibre. The results indicated that having $0.5 \%$ coir fibre in SCC enhanced the compressive, tensile, and flexural strength. Based on previous studies, the mechanical properties of coir fibre were added to SCC. Hence, the adoption of coir fibre in SCC will reduce solid waste and solve corrosion problems which occur due to the utilisation of steel in SCC.

\section{METHODS AND MATERIALS}

After the literature review and gaining a better understanding of fibre-reinforced self-compacting concrete, the following work methodology was formulated. First, the physical properties, namely specific gravity and water absorption of the materials, being aggregate, cement, and coir fibre, were measured according to ASTM C136 and ASTM C642, respectively. Flow characteristics of SCC-CF were studied through the slump flow test by utilising BS EN 12350-8. Test specimens were cast to study the hardened properties of SCC-CF, namely compressive and split tensile strength, respectively, for seven days and 28 days. The BS 12390-3:2009 and BS 12390-6:2009 standards were followed to investigate the compressive and tensile strength of self-compacting concrete containing the coir fibres. 


\subsection{Fine and Coarse aggregate}

Fine and coarse aggregates conforming to BS EN 12620 [22] were used for this study. The coarse aggregates were passed through a $20 \mathrm{~mm}$ sieve, and the fine aggregates were passed through a $5 \mathrm{~mm}$ sieve. The physical properties of the fine and coarse aggregates are presented in Table 1 and Figure 1, indicating that the coarse and fine aggregates were 2.62 and 2.59 heavier than water, respectively, making the SCC dense and enhancing its strength.

Table 1. The results of experimental research and computer calculations

\begin{tabular}{|l|l|l|}
\hline Properties & Fine Aggregate & Coarse Aggregate \\
\hline Specific gravity & 2.59 & 2.62 \\
\hline Water Absorption (\%) & 1.10 & 1.58 \\
\hline
\end{tabular}

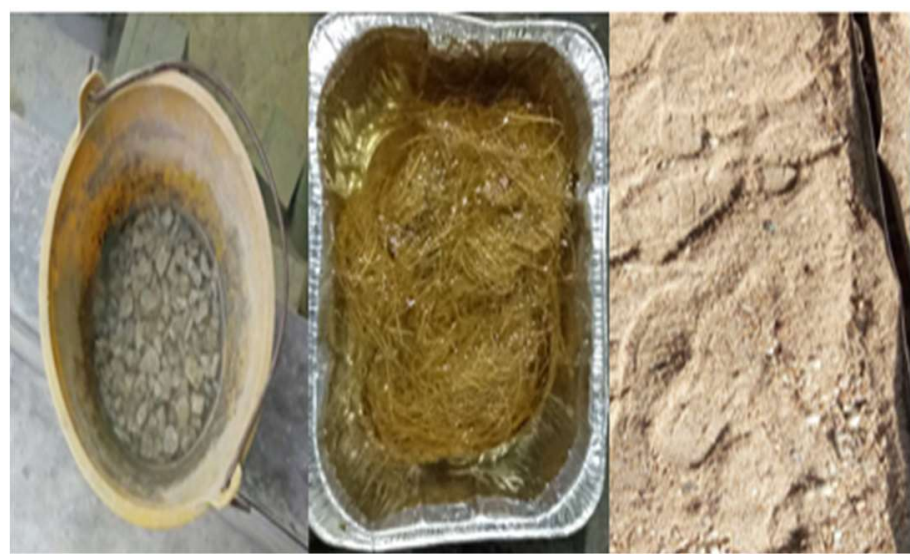

Fig. 1. Water absorption of aggregates and coir fibre

\subsection{Cement}

Ordinary Portland cement (OPC), called TASEK, was utilised in this research, conforming to MS EN 197-1:2014 [23]. The specific gravity of the OPC obtained from experimental work was 3.08 .

\subsection{Coir fibre}

Coir fibres are natural fibres that are extracted from the coconut shell. Generally, coir fibre length ranges from $90 \mathrm{~mm}$ to $250 \mathrm{~mm}$. Coir fibre has excellent resistance to impact load because it is both rigid and stiff compared to other natural fibres. There are many other advantages of coconut fibre such as resistant to fungi and rot. It also provides good insulation against temperature and sound, is tough and durable, not easily combustible, and easy to clean. These characteristics were beneficial for later use in the self-compacting concrete. Coconut fibre represents a large proportion of the agricultural waste produced in the tropics. In this study, 
the length of the coir fibres used ranged between $30 \mathrm{~mm}$ to $50 \mathrm{~mm}$. Vegetation and dust were removed from the fibres, as shown in Figure 2. The physical properties such as water absorption, specific gravity, and coir fibre density were obtained and are presented in Table 2.

Table 2. Physical properties of Coir fibres

\begin{tabular}{|c|c|}
\hline Properties & Results \\
\hline Specific gravity & 1.14 \\
\hline Water Absorption (\%) & 67 \\
\hline Density (g/cc) & 1.18 \\
\hline Length (mm) & 50 \\
\hline
\end{tabular}

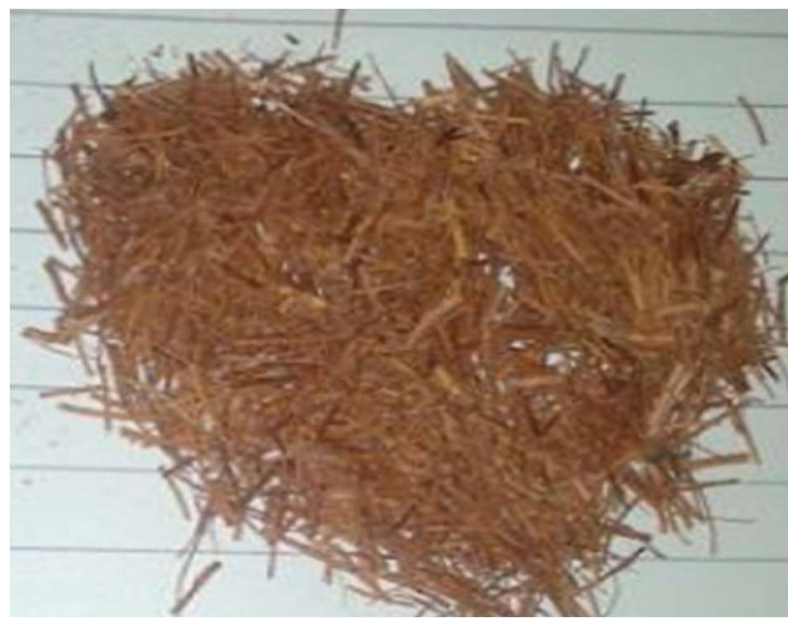

Fig. 2. Preparation of coir fibres

\subsection{Water}

Ordinary portable water which fulfils BS EN 1008:2002 [24] was used for the entire experimental investigation and the curing of specimens.

\subsection{Admixtures}

According to ASTM C494 Type E (Water-reducing and accelerating admixtures), the super plasticiser ESTOP was used. ESTOP is a non-toxic brown liquid based on sulphurated naphthalene formaldehyde condensates. ESTOP is a high-range water-reducing admixture for concrete and grouts, confirming to BS 5075: part 3 [25], see Figure 3. It was used to produce both high strength concrete and flowing concrete without addition of extra water. 


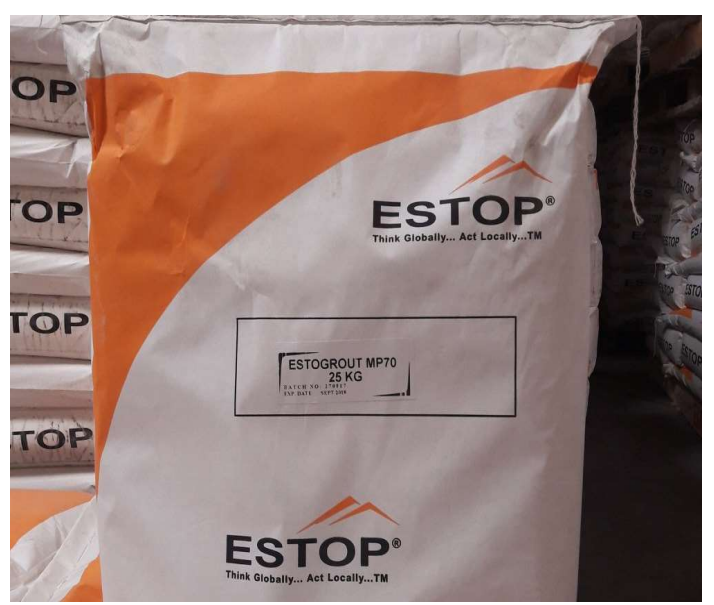

Fig. 3. ESTOP super plasticizer admixtures

\section{PREPARATION AND TESTING OF SPECIMENS}

M30 grade SCC was designed using EFNARC 2005 SCC guidelines for specifications [27]. A pilot study was conducted to achieve a ratio where an appropriate slump flow and $30 \mathrm{MPa}$ compressive factor were achieved. The ratio obtained was 1:2:1.5 (cement: sand: coarse aggregate), and the water-cement ratio was 0.45 . The calculation of materials for $1 \mathrm{~m} 3$ is presented in Table 3 .

Table 3. Quantity of cement, sand, coarse aggregate, water, and admixture for M30 grade concrete

\begin{tabular}{|c|c|c|c|c|c|}
\hline $\begin{array}{c}\text { Mix } \\
\text { proportion }\end{array}$ & $\begin{array}{c}\text { Composite } \\
\text { cement } \\
\left(\mathrm{Kg} / \mathrm{m}^{3}\right)\end{array}$ & $\begin{array}{c}\text { Sand } \\
\left(\mathrm{Kg} / \mathrm{m}^{3}\right)\end{array}$ & $\begin{array}{c}\text { Coarse } \\
\text { aggregate } \\
\left(\mathrm{Kg} / \mathrm{m}^{3}\right)\end{array}$ & $\begin{array}{c}\text { Water } \\
\left(\mathrm{Kg} / \mathrm{m}^{3}\right)\end{array}$ & $\begin{array}{c}\mathrm{Admixture} \\
\left(\mathrm{Kg} / \mathrm{m}^{3}\right)\end{array}$ \\
\hline $\begin{array}{c}\text { SCC for } \\
\text { M30 Grade } \\
\text { concrete }\end{array}$ & 440 & 880 & 660 & 198 & 4.4 \\
\hline
\end{tabular}

In this study, the coir fibres were used in different proportions, being $0 \%, 0.25 \%$, $0.5 \%, 1 \%$, and $1.5 \%$ by weight of cement. Properties such as slump flow were then measured. The hardened properties being compressive, tensile, and flexural strength of the resulting self-compacting concrete consisting of coir fibres were then investigated. The three samples of cubes and cylinders, having dimensions of $150 \times 150 \times 150 \mathrm{~mm}$ cube and $100 \mathrm{~mm} \varnothing \times 300 \mathrm{~mm}$ cylinder, are shown in Figures 4, 5, and 6 for compressive and tensile strength of SCC, respectively, at 7 and 28 days for water curing for each proportion. 


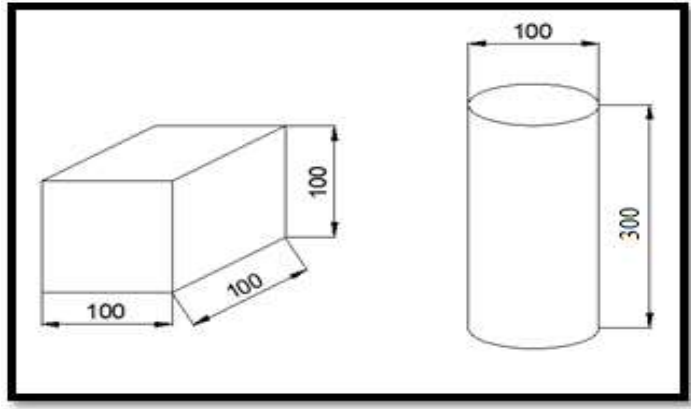

Fig. 4. Dimensions of the cubes and cylinders

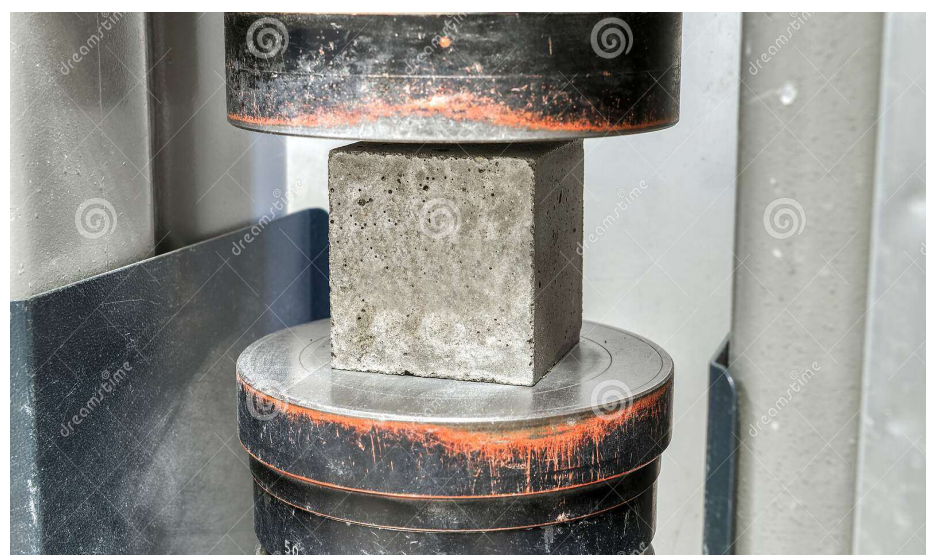

Fig. 5. Testing of an SCC specimen under compressive Strength

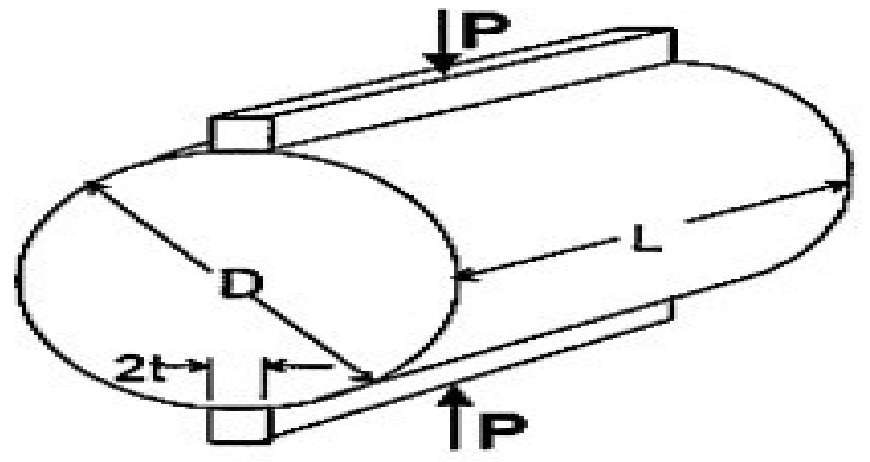

Fig. 6. Testing of an SCC specimen under tensile Strength 


\section{RESULTS AND DISCUSSION}

In this study, the fresh-state property, slump flow (filling ability), was examined. The hardened properties of compressive and tensile strength of the SCC were analysed for samples containing coir fibres at different curing regimes.

\subsection{Slump Flow of SCC-CF}

The slump flow (filling ability) outcomes for SCC containing coir fibres are presented in Figures 7 and 8. The results demonstrated that the slump flow (filling ability) rapidly decreases with increasing coir fibre percentage because the coir fibre increases the internal resistance to flow of the SCC. The slump flow was achieved as demonstrated in the EFNARC specification at $1 \%$ of coir fibre addition; beyond that, slump flow decreases almost $50 \%$ at $1.5 \%$ coir fibre addition in SCC. The decrease in slump flow is due to the fibre's resistance and so the adhesion between the mix particles becomes poor. A similar trend in slump flow of SCC containing CF was obtained by Chen [24] who also examined the fresh state properties of SCC containing coir fibres. The results demonstrate that the slump flow significantly decreased with the incorporation of CF in SCC.

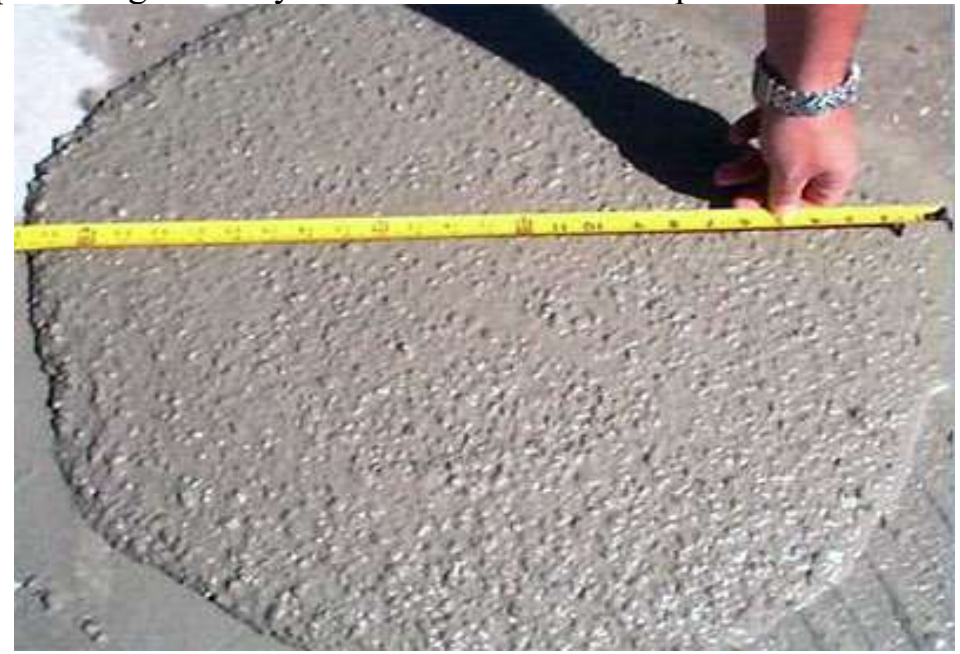

Fig. 7. Testing the Slump flow of SCC containing CF 


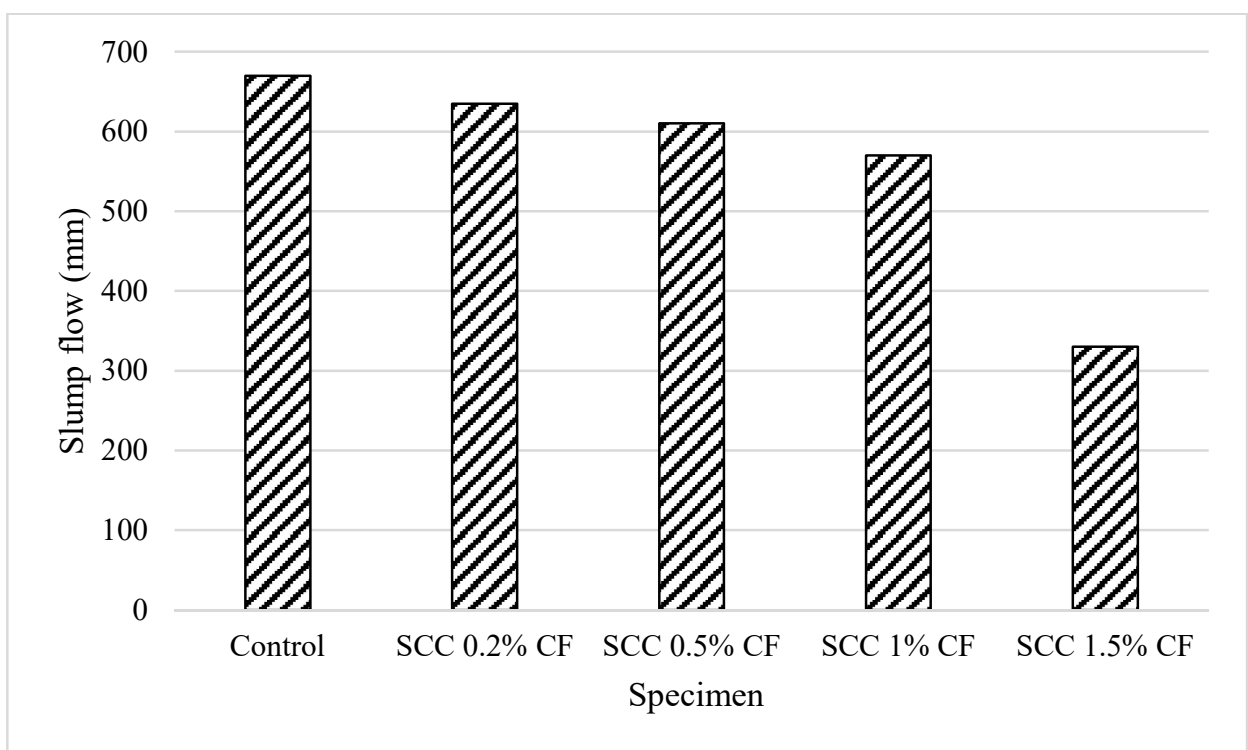

Fig. 8. Slump flow of SCC containing CF

\subsection{Compressive strength of SCC-CF}

The SCC-control and SCC-CF samples were analysed for compressive strength after 7 and 28 days of water curing, as presented in Figure 7 . The outcomes are presented in Figure 9 and demonstrate that the compressive strength significantly increases because the coir fibre enhances the internal capacity to resist the compression stresses. The addition of coir fibre up to $0.5 \%$ increases compressive strength, then strength rapidly decreases for further addition of coir fibres. The rapid decrease in strength is because the water absorption of CF is high So, the cement chemical reaction did not occur properly, and the internal bonding between the particles became poor. The optimum percentage is $0.5 \% \mathrm{CF}$ addition in SCC, where maximum compressive strength is obtained; $10 \%$ to $15 \%$ strength increases compared to the control sample of SCC. According to Mohamad [25] and Lakhiar [7], the compressive strength of concrete increases with the incorporation of coir fibres because the CF fills the voids which were present in the concrete mix, making the concrete more ductile and improving the internal bonding between the particles, thereby reducing the brittleness in the SCC which contributes to the greater strength. 


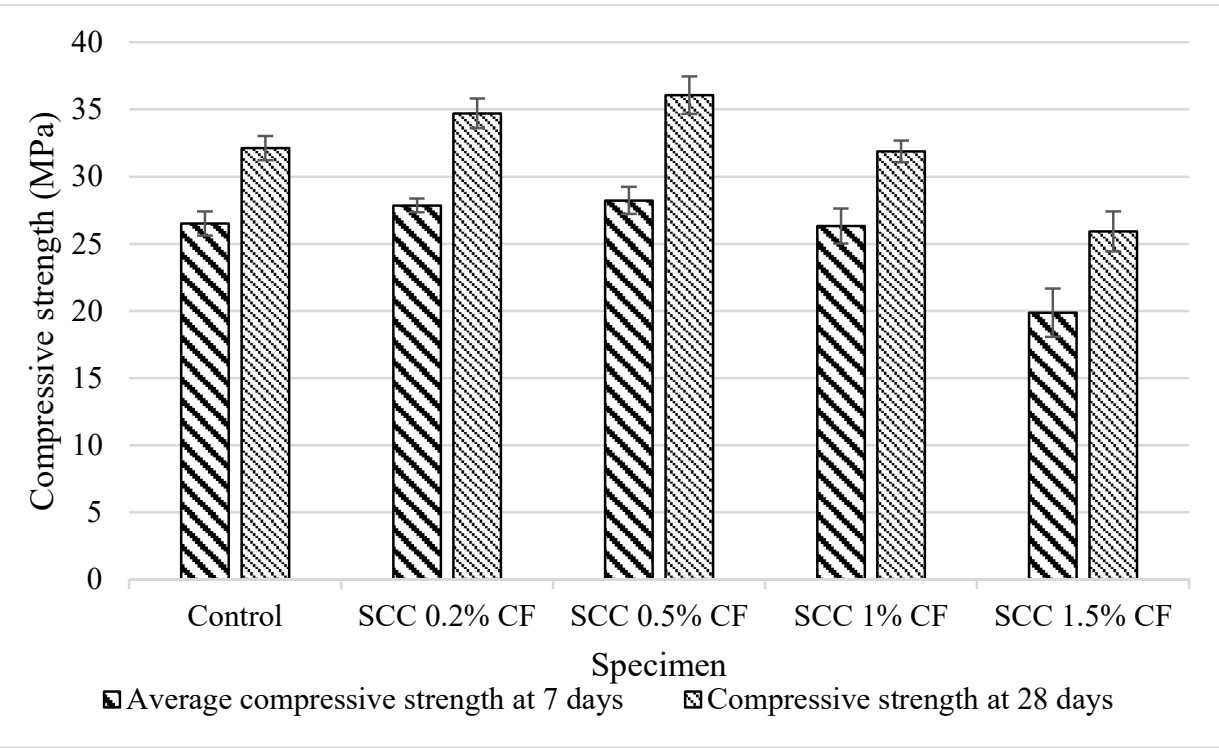

Fig. 9. The Compressive Strength of SCC containing CF

\subsection{Tensile Strength of SCC-CF}

The SCC and SCC-CF were analysed for tensile strength performance after 7 and 28 days of water curing, in a Universal testing machine, as shown in Figure 10. The results show that the tensile strength increases rapidly when coir fibre is incorporated up to $0.5 \%$ because the fibres have a tendency to enhance the tensile strength capacity up to certain amount. Then, the strength reduced for further incorporation of coir fibres in SCC, mainly because the water absorption of CF is high. The cement chemical reaction did not occur properly, and the internal bonding between the particles became poor. The optimum percentage is $0.5 \% \mathrm{CF}$ addition in SCC, where maximum tensile strength is obtained; $20 \%$ to $35 \%$ strength increases compared to the control sample of SCC. Valasek [26] and Manjula [27] also investigated SCC containing CF and found that the tensile strength was significantly increased when CF was added up to $0.5 \%$ by weight of cement. The tensile strength then decreased with further addition of CF. Similar behaviour for tensile strength when $\mathrm{CF}$ was added to the SCC was seen in this study. 


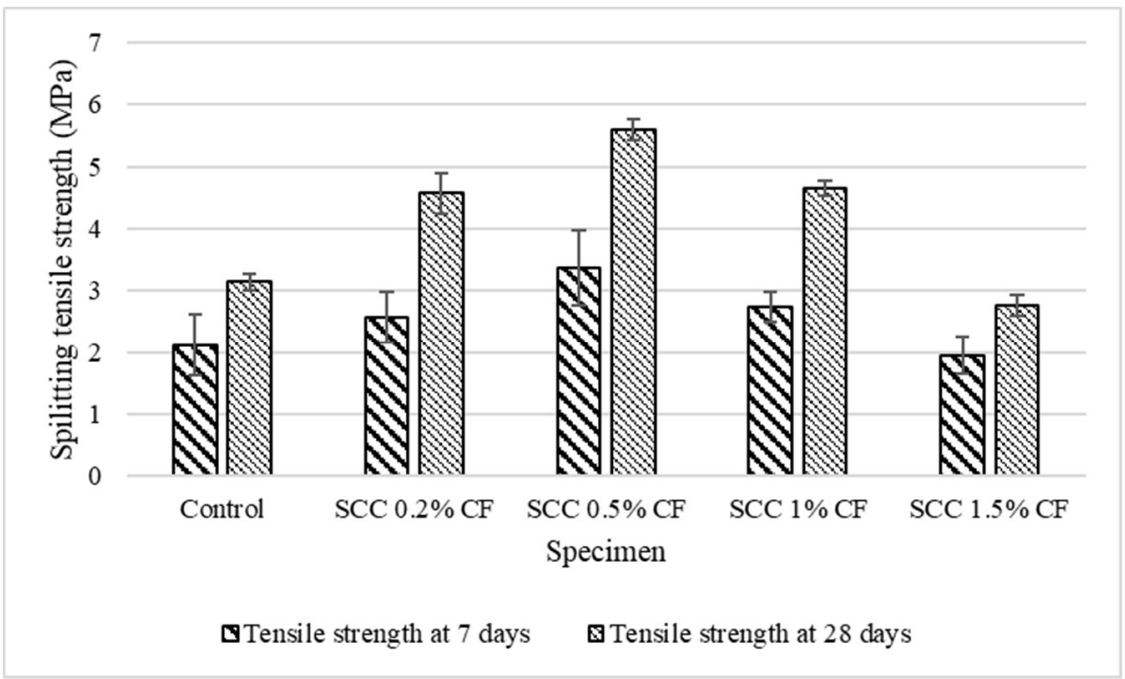

Fig. 10. Tensile Strength of SCC containing CF

\section{STATISTICAL ANALYSIS}

To analyse the outcomes in the compressive and tensile strength, statistical analysis was done using ANOVA software. Although the difference in compressive strength between the control and SCC with coir fibres is notable, statistically this cannot be considered significant. Thus, statistical analysis was performed to find the P-value for the compressive and splitting tensile strength differentiation; whether or not the difference indicates anything consequential. Table 4 presents the P-value of compressive strength for SCC as 0.153 , which is greater than 0.05 ; therefore, it can be concluded that this is not statistically significant. As for splitting tensile strength, as shown in Table 5, the differentiation in strength ranged from 3.15 to $5.6 \mathrm{MPa}$ in the statistical analysis; this indicates that the P-values for SCC mixtures were less than 0.05 ; thus, the differentiation can be categorised as statistically significant.

Table. 4. Statistical analysis of compressive strength

\begin{tabular}{|c|c|c|c|c|}
\hline Specimen & $\begin{array}{c}\text { Average } \\
\text { Compressive } \\
\text { strength (MPa) }\end{array}$ & Variance & $\begin{array}{c}\text { Standard } \\
\text { deviation }\end{array}$ & \\
\hline Control & 32.13 & 2.1 & 0.9 & \multirow{2}{*}{0.153} \\
\hline SCC $0.2 \%$ CF & 34.71 & 1.94 & 1.1 & \\
\cline { 1 - 4 } SCC $0.5 \%$ CF & 36.06 & 1.84 & 1.4 & \\
\hline SCC 1\% CF & 31.88 & 1.52 & 0.8 & \\
\cline { 1 - 4 } SCC $1.5 \%$ CF & 25.92 & 1.32 & 1.5 & \\
\hline
\end{tabular}


Table. 5. Statistical analysis of splitting tensile strength

\begin{tabular}{|c|c|c|c|c|}
\hline Specimen & $\begin{array}{c}\text { Average } \\
\text { Compressive } \\
\text { strength (MPa) }\end{array}$ & Variance & $\begin{array}{l}\text { Standard } \\
\text { deviation }\end{array}$ & p-value \\
\hline Control & 3.15 & 0.0029 & 0.13 & \multirow[t]{5}{*}{0.0174} \\
\hline SCC $0.2 \%$ CF & 4.57 & 0.0024 & 0.32 & \\
\hline$\overline{S C C ~} 0.5 \%$ CF & 5.6 & 0.0022 & 0.17 & \\
\hline SCC 1\% CF & 4.64 & 0.002 & 0.12 & \\
\hline SCC $1.5 \%$ CF & 2.76 & 0.0019 & 0.16 & \\
\hline
\end{tabular}

\section{CONCLUSION}

After the extensive literature review, and after identifying the need for detailed studies on self-compacting concrete and its composite with the addition of coir fibres, the following general conclusions can be drawn. Several areas for further work are also identified and presented. The general conclusions drawn based on the experimental investigations carried out in this study are as follows:

i. The slump flow decreases with fibre content increase because the coir fibres increase the concrete's resistance.

ii. The full coir fibre content used in the present investigation in SCC is $1 \%$, where the slump flow is $16.67 \%$ less than the reference slump flow value.

iii. At a coir fibre content of $1.5 \%$, the mix proportion of SCC for the M30 grade of concrete has to be revised, especially concerning the more adequate portions. The mix will be consistent, without separation of coir fibres from the cement matrix.

iv. The maximum compressive strength of SCC containing coir fibre is at $0.5 \%$ fibre content. It has $43 \%$ higher compressive strength than the reference mix of SCC.

v. There is no strength loss across the age of curing from 7 days to 28 days for the SCC containing CF. Instead, the compressive strength improved in the range of $29 \%$ to $48 \%$ up to $0.5 \%$ addition of coir fibre, after which strength loss occurred of between $5 \%$ to $15 \%$ compared to the control SCC.

vi. The maximum split tensile strength of CFRSCC is at $0.5 \%$ fibre content, and is $32.17 \%$ higher than the split tensile strength of the reference mix of SCC.

vii. A similar pattern to compressive strength was seen in tensile behaviour; the strength decreased when the coir fibre was incorporated beyond $0.5 \%$ by weight of cement. However, although at $1 \%$ coir fibre content, SCC possesses almost $32 \%$ higher tensile strength, it is $17 \%$ less than SCC containing $0.5 \%$ coir fibre. Beyond $1 \%$ coir fibre in SCC, tensile strength decreased by $12 \%$ compared to the control sample. 
It can be summarised that the utilisation of coir fibres in the development of green SCC helps resolve the problem of coconut waste disposal and environmental pollution and contributes to an improvement in compressive and tensile strength.

\section{REFERENCES}

1. Salzer, C, Wallbaum, H, Ostermeyer, Y, and Kono, J 2017. Environmental performance of social housing in emerging economies: life cycle assessment of conventional and alternative construction methods in the Philippines. The International Journal of Life Cycle Assessment 22, 1785-1801.

2. Max, Smyth 2018. A Study of the Viability of Cross Laminated Timber for Residential Construction, Masters thesis. Stockholm: Stockholm University.

3. Demiss, BA, Oyawa, WO, and Shitote, SM 2018. Mechanical and microstructural properties of recycled reactive powder concrete containing waste glass powder and fly ash at standard curing. Cogent Engineering 5, 146157.

4. Mohamad, N, Iman, MA, Samad, AAA, Mydin, MAO, Jusoh, S, Sofia, A and Lee, B 2019. Flexure Behaviour of Foamed Concrete Incorporating Banana Skin Powder and Palm Oil Fuel Ash Strengthened with Carbon Fibre Reinforced Plate. IOP Conference Series: Materials Science and Engineering 601, 012025.

5. Gebremariam, ATT 2018. Development of Self-Compacting Translucent Concrete Incorporating Recycled Glass Aggregate for Sustainable Construction, $\mathrm{PhD}$ thesis. Kenya Pausti: Pan African University.

6. Ahmad, S 2017. Use of alternative waste materials in producing ultra-highperformance concrete. In MATEC Web of Conferences EDP Sciences. 120, 03014.

7. Saketh, C, Patel, JM, Rajesh, M, Sadanand, G and Manoj, M 2017. Statistical analysis of polypropylene fibre reinforced concrete. International Journal of Advance Research, Ideas and Innovations in Technology 3, 518-532.

8. Tang, WC, Wang, Z, Liu, Y and Cui, HZ 2018. Influence of red mud on fresh and hardened properties of self-compacting concrete. Construction and Building Materials 178, 288-300.

9. Lakhiar, MT, Sohu, S, Bhatti, IA, Bhatti, N, Abbasi, SA and Tarique, M 2018. Flexural Performance of Concrete Reinforced by Plastic Fibers. Engineering, Technology \& Applied Science Research 8, 3041-3043.

10. Carlsson, R, Elmquist, L and Johansson, C 2017. Cast metal with intelligencefrom passive to intelligent cast components. In VIII ECCOMAS Thematic Conference on Smart Structures and Materials, SMART.

11. Elhafez, SA, Hamad, HA, Zaatout, AA and Malash, GF 2017. Management of agricultural waste for removal of heavy metals from aqueous solution: 
adsorption behaviors, adsorption mechanisms, environmental protection, and techno-economic analysis. Environmental Science and Pollution Research 24, 1397-1415.

12. Manahan, SE 1999. Industrial ecology: environmental chemistry and hazardous waste. CRC Press.

13. Majid, A, Anthony, L, Hou, S and Nawawi, C 2011. Mechanical and dynamic properties of coconut fiber reinforced concrete. Construction and Building Materials 30, 112-125.

14. Jani, SM and Rushdan, I 2014. Effect of bleaching on coir fibre pulp and paper properties. Journal of Tropical Agriculture and Food Science 42, 51-61.

15. Lif, SL, Shahiron, S, Mohamad, SS, Nurul, IIR, H 2016. A Preliminary Study On Chemical And Physical Properties Of Coconut Shell Powder As A Filler In Concrete. Materials Science and Engineering 160, 1-7.

16. Jhatial, AA, Sohu, S, Bhatti, NK, Lakhiar, MT and Oad, R 2018. Effect of steel fibres on the compressive and flexural strength of concrete. International journal of advanced and applied sciences 5, 16-21.

17. Athiyamaan, V and Ganesh, GM 2020. Experimental, statistical and simulation analysis on impact of micro steel-Fibres in reinforced SCC containing admixtures. Construction and Building Materials 246, 118450.

18. Ghorbani, S, Sharifi, S, Rokhsarpour, H, Shoja, S, Gholizadeh, M, Rahmatabad, MAD and de Brito, J 2020. Effect of magnetized mixing water on the fresh and hardened state properties of steel fibre reinforced selfcompacting concrete. Construction and Building Materials 248, 118660.

19. Tahir, M 2018. Structural performance of precast self-compacting concrete beam consisting banana skin powder and coir fibre under flexural load, $\mathrm{PhD}$ thesis. Johar: Universiti Tun Hussein Onn Malaysia.

20. Vidyasagar, K, Pradesh, A and Naidu, CD 2018. Influence of polypropylene fibers with admixtures in strengthening of concrete.

21. Amirtharaj, J 2017. Effects of Coir Fiber on Self Compacting Concrete. International Journal for Scientific Research \& Development 5, 1373-1375.

22. EN, B 2002. 12620. Aggregates for Concrete. British Standard Institute, Brussels.

23. Malaysian Standard "MS EN 197-1:2014: Cement - Part 1: Composition, specifications and conformity criteria for common cements (First revision)". (2014).

24. EN, B 2002. 1008, Mixing water for concrete. British Standards Institution: London, UK.

25. British Standards Institution, 1985. BS 5075: Part 3. Specification for superplastisizing admixtures. 
26. Admixture, HCW, Nonchloride, noncorrosive, accelerating admixture complying with ASTM C 494. Type C, and recommended by the manufacturer for use in masonry mortar of composition indicated.

27. EFNARC, S 2002. Guidelines for self-compacting concrete. London, UK: Association House, 32, 34.

28. Iman, MA, Mohamad, N, Samad, AAA, Goh, WI, Mydin, MO, Tambichik, MA, Bosro, MZM, Wirdawati, A and Jamaluddin, N 2018. Precast selfcompacting concrete (PSCC) panel with added coir fiber: An overview. In IOP Conference Series: Earth and Environmental Science. IOP Publishing, 140,012138

29. Chen, J and Chouw, N 2018. Flexural behaviour of flax FRP double tube confined coconut fibre reinforced concrete beams with interlocking interface. Composite Structures 192, 217-224.

30. Mohamad, N, Iman, MA, Samad, AAA, Mydin, MAO, Jusoh, S, Sofia, A, Aziz, K and Lee, B 2019. Flexure Behaviour of Foamed Concrete Incorporating Banana Skin Powder and Palm Oil Fuel Ash Strengthened with Carbon Fibre Reinforced Plate. In IOP Conference Series: Materials Science and Engineering, IOP Publishing. 601, 012025.

31. Lakhiar, MT, Sohu, S, Bhatti, IA, Bhatti, N, Abbasi, SA and Tarique, M 2018. Flexural Performance of Concrete Reinforced by Plastic Fibers. Engineering, Technology \& Applied Science Research 8, 3041-3043.

32. Valášek, P, D'Amato, R, Müller, M and Ruggiero, A 2018. Mechanical properties and abrasive wear of white/brown coir epoxy composites. Composites Part B: Engineering 146, 88-97.

33. Manjula, R, Raju, NV, Chakradhar, RPS and Johns, J 2018. Effect of thermal aging and chemical treatment on tensile properties of coir fiber. Journal of natural fibers 15, 112-121.

Editor received the manuscript: 10.01.2021 